\title{
IMPROCEDÊNCIA LIMINAR DO PEDIDO POR PRESCRIÇÃO E A VIOLAÇÃO DA AUTONOMIA PRIVADA
}

\author{
SUMMARY JUDGMENT AGAINST THE CLAIM \\ DUE THE EXTINCTIVE PRESCRIPTION AND \\ VIOLATION OF PRIVATE AUTONOMY
}

ANDRÉ CORDEIRO LEAL ${ }^{1}$

VINÍCIUS LOTT THIBAU ${ }^{2}$

\section{RESUMO}

O artigo examina os pressupostos e desdobramentos do julgamento liminar pela improcedência do pedido em razão da verificação, pelo juiz, da ocorrência da prescrição. Para tanto, além de abordar os dispositivos que tratam do tema no Código de Processo Civil brasileiro de 2015, indicando distinções e aproximações em relação às normas que dispunham sobre a temática no Código de Processo Civil de 1973, debruça-se sobre a questão da intromissão do judiciário na autonomia privada, cuja existência é assegurada pela Constituição de 1988. No escrito, apontam-se as inconsistências do referido julgamento diante não só das codificações civil e procedimental civil, como também do discurso constitucional brasileiro. A pesquisa formalizada, de base bibliográfica e documental, é, quanto ao seu objetivo, exploratória e explicativa, adotando, ainda, os métodos comparativo e hipotético-dedutivo. Elege a proposição neoinstitucionalista do processo como marco teórico.

Palavras-chave: Improcedência liminar do pedido. Prescrição. Autonomia privada.

1 Doutor e Mestre em Direito Processual pelo Programa de Pós-Graduação Stricto Sensu em Direito da Pontifícia Universidade Católica de Minas Gerais. Professor Titular da Universidade FUMEC, onde leciona nos cursos de Graduação (Teoria Geral do Processo e Direito Processual Civil) e Pós-Graduação Stricto Sensu (Mestrado em Instituições Sociais, Direito e Democracia). Professor de Teoria Geral do Processo e Direito Processual Civil no curso de Graduação em Direito da Faculdade Mineira de Direito da Pontifícia Universidade Católica de Minas Gerais. Professor do Curso de Pós-Graduação Lato Sensu do Instituto de Educação Continuada da PUC Minas. Advogado e Economista. ORCID iD: https://orcid.org/00000002-0985-7030. E-mail: andrecleal28@gmail.com.

2 Doutor e Mestre em Direito Processual pelo Programa de Pós-Graduação Stricto Sensu em Direito da Pontifícia Universidade Católica de Minas Gerais. Professor de Direito Processual Civil no Curso de Graduação em Direito da Escola Superior Dom Helder Câmara, nas modalidades integral e convencional. Professor de Direito Processual Civil no Curso de Pós-Graduação Lato Sensu em Advocacia Cível da Escola Superior de Advocacia da OAB/MG. Professor de Direito Processual Civil no Curso de Pós-Graduação Lato Sensu em Direito Processual Civil e Métodos Alternativos de Resolução de Conflitos do Instituto de Educação Continuada da PUC Minas. Advogado. ORCID iD: https://orcid.org/0000-0002-8225-8026. E-mail: viniciusthibau@yahoo.com.br. 


\section{ABSTRACT}

The article examines the assumptions and consequences of the summary judgment against the claim due the verification, by the judge, of the occurrence of the extinctive prescription. To this end, examines the legal provisions of the Brazilian Civil Procedure Code of 2015, pointing out distinctions and approximations in relation to the legal provisions of the Brazilian Civil Procedure Code of 1973, focusing the meddling of the judiciary in private autonomy, which was ensured by the 1988 Brazilian Constitution. In the writings, the inconsistencies of this kind of judgment are indicated, considering not only the civil and procedural civil codifications, but also the Brazilian constitutional discourse. The formalized research, based on bibliography and documents, is exploratory and explanatory in its objective, also adopting the comparative and hypothetical-deductive methods. It elects the neoinstitutionalist theory of the process as a theoretical background.

Keywords: Summary judgment against the claim. Extinctive prescription. Private autonomy.

\section{INTRODUÇÃO}

Em 7 de fevereiro de 2006, foi publicada a Lei n 11.277, que buscava atribuir "racionalidade e celeridade ao serviço de prestação jurisdicional" (BRASIL, 2004). A lei que acrescentou o art. 285-A ao Código de Processo Civil de 1973 previa a possibilidade do julgamento liminar pela improcedência do pedido, que ganhou novos contornos com a edição da Lei $n^{\circ}$ 13.105, de 16 de março de 2015.

Com o advento do Código de Processo Civil de 2015, a improcedência liminar do pedido é autorizada, dentre outras hipóteses, quando o juiz verifica a ocorrência da prescrição, antes mesmo de determinar a citação da parte ré. Trata-se, no entanto, de uma faculdade questionável, inclusive sob a perspectiva do direito privado, uma vez que, pelo exercício da opção disposta no art. $332, \S 1^{\circ}$, do $\mathrm{CPC} / 15$, afasta-se a possibilidade de renúncia à prescrição no espaço procedimental pré-decisório e, de conseguinte, veda-se a oportunidade de cumprimento da obrigação natural advinda da extinção, pelo tempo, da pretensão deduzida em juízo pela parte autora.

Assim é que, além de todas as dificuldades correlacionadas com o reconhecimento da prescrição, de ofício, pelo magistrado, o Código de Processo Civil vigente deixa de considerar que, com o estabelecimento do paradigma do Estado Democrático de Direito no Brasil, sofreram ressemantização a "dicotomia público/privado e a racionalidade do ordenamento jurídico" (CASTRO, 2010, p. 223), motivo pelo qual, desde 1988, o Estado brasileiro não mais pode se apropriar de um espaço que foi teorizado para o exercício da liberdade individual.

Diante disso, a hipótese que se objetiva testar, no escrito formalizado, é a de que a improcedência liminar do pedido por prescrição viola o direito constitucional à autonomia privada, que, no direito democrático, não pode ser afastado em prol da eficiência que, já a partir da atuação da comissão de juristas notáveis nomeada pelo Senado Federal à elaboração do Anteprojeto do Código de Processo Civil, foi anunciada como um dos escopos a serem implementados pela legislação a ser publicada. ${ }^{3}$

3 A comissão de juristas notáveis responsável pela produção do Anteprojeto de Código de Processo Civil foi instituída, no Senado Federal, pelo Ato do Presidente $n^{\circ} 379 / 2009$. Ao longo de sua atuação, a assembleia de especialistas contou com a participação de Luiz Fux (presidente), Tereza Arruda Alvim Wambier (relatora-geral), Adroaldo Furtado Fabrício, Humberto 
Em relação à abordagem do problema da incompatibilidade paradigmática da improcedência liminar do pedido, portanto, a pesquisa adota os métodos comparativo e hipotético-dedutivo (POPPER, 2009, 2004, 1999). Acolhendo a proposição neoinstitucionalista do processo como marco teórico (LEAL, 2017, 2016a, 2016b, 2013), a pesquisa é exploratória e explicativa quanto ao objetivo e, pelas técnicas empregadas, é bibliográfica e documental.

\section{IMPROCEDÊNCIA LIMINAR DO PEDIDO E O RECONHECIMENTO DA PRESCRIÇÃO PELO JUIZ SOLIPSISTA}

A improcedência liminar do pedido está normatizada, no Brasil, embora sob rótulo diverso, desde o ano de 2006, quando entrou em vigor a Lei $n^{\circ} 11.277$, que dispôs sobre o denominado julgamento de processos repetitivos. ${ }^{4}$ De acordo com essa lei, que acresceu o art. 285-A ao Código de Processo Civil de 1973, o julgamento liminar pela improcedência do pedido era autorizado quando a matéria controvertida fosse unicamente de direito e, no juízo em que tramitasse o procedimento, já houvesse sido proferida sentença de total improcedência em outros casos idênticos. Segundo a Lei $n^{\circ} 11.277 / 06$, nessa hipótese, poderia ser dispensada a citação da parte ré e, imediatamente, proferida a sentença, reproduzindo-se o teor da decisão anteriormente prolatada.

Com efeito, pela legislação publicada em 2006, a verificação da prescrição da pretensão deduzida pela parte autora, no primeiro momento destinado à análise da petição inicial, não era apontada como hipótese autorizativa da improcedência liminar do pedido. No Código de Processo Civil de 1973 , por seu art. 219 , $\S 5^{\circ}$, o juiz estava obrigado a pronunciar, de ofício, a prescrição, inclusive antes da citação da parte ré, mas, ao contrário do que dispõe o Código de Processo Civil de 2015, essa atitude dizia respeito ao indeferimento da petição inicial.

É, por isso, que, focando o Código de Processo Civil de 1973, é possível afirmar que nem todas as hipóteses determinativas do indeferimento da petição inicial estavam relacionadas com a existência dos chamados vícios processuais insanáveis, diversamente do que se estampa no Código de Processo Civil de 2015. A inclusão normativa da prescrição como causa de indeferimento da petição inicial exigia, paradoxalmente, ${ }^{5}$ o proferimento de uma decisão resolutiva de mérito antes mesmo da citação da parte ré, de maneira oposta ao que ocorria quando o indeferimento da petição inicial baseava-se na inépcia dessa petição,

Theodoro Júnior, Paulo Cezar Pinheiro Carneiro, José Roberto dos Santos Bedaque, José Miguel Garcia Medina, Bruno Dantas, Jansen Fialho de Almeida, Marcus Vinicius Furtado Coelho, Elpídio Donizetti Nunes e Benedito Cerezzo Pereira Filho. (BRASIL, 2010).

4 Para acessar uma síntese do procedimento legislativo preparatório da Lei $n^{\circ} 11.277 / 06$, confira, principalmente, o artigo científico denominado Apontamentos críticos sobre a improcedência liminar do pedido, que foi produzido por Vinícius Lott Thibau (2019).

50 caráter paradoxal dessa possibilidade está em que, de acordo com a previsão expressa do art. 267, I, do CPC de 1973, o indeferimento da petição inicial era determinativo da extinção do processo sem resolução de mérito. Pelo art. 269 do CPC de 1973 , no entanto, a prescrição era apontada como uma das hipóteses em que o juiz deveria proferir sentença definitiva, isto é, resolutiva de mérito. 0 enfrentamento de referida assistematicidade apresenta-se relevante, uma vez que a expressão "de logo", presente apenas no art. 295, IV, do CPC de 1973, poderia dar a entender a existência de duas possibilidades de sentença relacionadas à verificação da prescrição: sem resolução de mérito, se a prescrição houvesse sido percebida já no primeiro exame judiciário da petição inicial, ou, ao contrário, com resolução de mérito, acaso essa percepção houvesse se dado em momento procedimental posterior. 
na manifesta ilegitimidade da parte, na ausência de interesse processual e, ainda, na falta de realização da emenda, que se apresentavam como situações impositivas da prolação de uma sentença terminativa.

O enquadramento taxionômico da prescrição como hipótese determinativa do indeferimento da petição inicial sempre causou estranhamento, uma vez que a prescrição é instituto jurídico que se relaciona com o denominado direito material. A normatização da ocorrência da prescrição como uma das situações impositivas do indeferimento da petição inicial, porém, não significou um deslize pontual do legislador, mas uma tentativa deliberada de ocultação da possibilidade de proferimento de uma decisão meritória encerradora do processo antes mesmo que estivesse formada a intitulada relação processual.

Se essa possibilidade estivesse prevista, de modo escancarado, pela lei, muitos poderiam ser os óbices impostos à sua aprovação, como se estampa no magistério de Araken de Assis $(2015$, p. 128, v. III):

O CPC de 1973 revelava-se avançado para sua época. A versão original do segundo código processual unitário já autorizava o indeferimento da petição inicial no caso de o juiz verificar o vencimento do prazo de prescrição ou de decadência. Era previsão de largo alcance, em parte camuflada dentre as hipóteses de sentença terminativa para evitar resistências mais contundentes. [...]

A localização do assunto relativo à prescrição e à decadência no âmbito do indeferimento da petição inicial revela-se formalmente imprópria. 0 juiz julga o mérito. Entretanto, na ocasião em que o CPC de 1973 entrou em vigor, dispositivo autônomo e destacado suscitaria melindres e oposição tenaz e, seja como for, o legislador não se atreveu ao passo ousado.

É de se registrar que, exatamente porque ligada ao chamado direito material, a prescrição jamais ocupou o rol das matérias preliminares referidas pelo art. 301 do Código de Processo Civil de 1973. Quanto a isso, aliás, nenhuma modificação trouxe o Código de Processo Civil de 2015, que, no entanto, cuidou de excluir o tema da prescrição das hipóteses determinativas do indeferimento da petição inicial, de modo a uniformizar a abordagem das situações que propiciam, por sentença terminativa, o juízo de admissibilidade negativo dessa petição.

Dessa forma, na atualidade, o indeferimento da petição inicial somente ocorrerá quando for identificada alguma das hipóteses previstas no art. 330 do Código de Processo Civil. Pelo rotulado Novo Código de Processo Civil brasileiro, ${ }^{6}$ a verificação da prescrição da pretensão deduzida pela parte autora no momento da primeira análise da petição inicial é autorizativa da improcedência liminar do pedido (art. $332, \S 1^{\circ}$, do CPC), a qual recebe críticas que, embora na vigência da codificação anterior já pudessem ser formuladas em relação ao indeferimento da petição inicial por prescrição, ganharam grande repercussão com o advento do Código de Processo Civil de 2015.

Isso porque, diversamente do que ocorreu com o Código de Processo Civil de 1973, que vigorou durante o período de restrição democrática no Brasil, o Código de Processo Civil de 2015 assumiu, expressamente, o compromisso de alinhar as suas normas às disposições Prova e jurisdicionalismo no novo CPC brasileiro, de autoria de André Cordeiro Leal e Vinícius Lott Thibau (2017). 
constitucionais, ${ }^{7}$ promessa a qual a Lei $n^{0} 13.105 / 15$ descumpriu, de modo ostensivo, também pelo regramento da improcedência liminar do pedido. É que, pela norma constante do art. $332, \S 1^{\circ}$, o Código de Processo Civil de 2015 viola o direito à autonomia privada que é constitucionalmente conferido à comunidade jurídica de legitimados ao processo (art. $1^{\circ} \mathrm{da}$ $\mathrm{CB}),{ }^{8}$ devassando, assim, o que Jürgen Habermas anuncia como "domínio intocável de configuração da vida privada" (2003, p. 137, v. II).

A verificação da prescrição pelo juiz, no primeiro momento dedicado ao exame da petição inicial, é, contudo, apenas mais uma das questionáveis hipóteses de cabimento do julgamento liminar pela improcedência, que, no Código de Processo Civil de 2015, está regulado da seguinte maneira:

Art. 332. Nas causas que dispensem a fase instrutória, o juiz, independentemente da citação do réu, julgará liminarmente improcedente o pedido que contrariar:

I - enunciado de súmula do Supremo Tribunal Federal ou do Superior Tribunal de Justiça;

II - acórdão proferido pelo Supremo Tribunal Federal ou pelo Superior Tribunal de Justiça, em julgamento de recursos repetitivos;

III - entendimento firmado em incidente de resolução de demandas repetitivas ou de assunção de competência;

IV - enunciado de súmula de tribunal de justiça sobre direito local.

$\S 1^{\circ}$. O juiz também poderá julgar liminarmente improcedente o pedido se verificar, desde logo, a ocorrência de decadência ou de prescrição.

$\S 2^{\circ}$. Não interposta a apelação, o réu será intimado do trânsito em julgado da sentença, nos termos do art. 241.

$\S 3^{\circ}$. Interposta a apelação, o juiz poderá retratar-se em 5 (cinco) dias.

$\S 4^{\circ}$. Se houver retratação, o juiz determinará o prosseguimento do processo, com a citação do réu, e, se não houver retratação, determinará a citação do réu para apresentar contrarrazões, no prazo de 15 (quinze) dias. (BRASIL, 2015).

Assim, por uma análise comparativa das normas hauridas dos arts. 285-A do Código de Processo Civil de 1973 e 332 do Código de Processo Civil de 2015, afere-se que, pela legislação vigente, o juiz está obrigado a julgar liminarmente improcedente o pedido sempre que esse contrariar um precedente obrigatório ou um enunciado de súmula do Supremo Tribunal

7 Na Exposição de Motivos do Código de Processo Civil de 2015, que, estranhamente, reproduz a que foi apresentada pela comissão de juristas notáveis nomeada pelo Senado Federal, consta que a "necessidade de que fique evidente a harmonia da lei ordinária em relação à Constituição Federal da República fez com que se incluíssem no Código, expressamente, princípios constitucionais, na sua versão constitucional. Por outro lado, muitas regras foram concebidas dando concreção a princípios constitucionais". (BRASIL, 2015, p. 26). No entanto, "extrai-se do CPC de 2015 que, a pretexto de ofertar respostas às mudanças exigidas pela Constituição a que tanto apela, apenas coloniza a própria constitucionalidade com conceitos arraigados em um direito processual civil tradicional, os quais se apresentam absolutamente desalinhados ao projeto democrático brasileiro que almeja superar os envelhecidos fundamentos ideológicos dos Estados Liberal e Social. Daí, ao se referir à Constituição brasileira, o que anuncia a Exposição de Motivos do CPC de 2015 é uma leitura às avessas da constitucionalidade que ele afirma obedecer, já que se ancora em conceitos que, por sua origem, são inconciliáveis com um projeto democrático não acolhedor da perspectiva histórico-civilizante dos povos conquistados." (LEAL; THIBAU, 2018, p. 42). 0 texto transcrito faz referência ao arcaísmo dos conceitos de ação, jurisdição e processo adotados pela Lei $n^{\circ}$ $13.105 / 15$

8 A expressão comunidade jurídica de legitimados ao processo é adotada como sinônimo de povo total pela teoria neoinstitucionalista do processo. Nesse sentido, confira, sobretudo, as publicações de Rosemiro Pereira Leal (2017a, 2017b, 2016a, 2016b, 2011, 2010, 2009, 2008, 2006). 
Federal, do Superior Tribunal de Justiça ou do Tribunal de Justiça, sendo que, quanto a este, se o enunciado disser respeito ao direito local. Diversamente do que previa a norma disposta no art. 285-A do Código de Processo Civil de 1973, no Código de Processo Civil de 2015, julgar liminarmente improcedente o pedido não é uma faculdade deferida ao magistrado, salvo quando esse verificar, desde logo, a prescrição e a decadência.

Além disso, pela normatização da improcedência liminar do pedido no Código de Processo Civil de 2015, outras alterações são notadas quanto ao que foi estabelecido pela Lei n 11.277/06. Como afirma Trícia Navarro Xavier Cabral (2016), pelo art. 332 do Código de Processo Civil vigente:

[...] (b) o critério legislativo de aplicação deixou de ser a existência de matéria unicamente de direito e passou a ser as causas que dispensem a fase instrutória; (c) foi retirada a exigência de outros julgados no mesmo juízo; (d) o requisito legal passou a ser somente a existência de entendimentos firmados pelos tribunais hierarquicamente superiores; (e) houve previsão expressa aos casos de prescrição e decadência; e (f) no aspecto procedimental, em caso de não haver retratação, o réu deverá ser intimado do trânsito em julgado da decisão.

Por tudo isso, porção da literatura especializada aduz que a previsão normativa atual da improcedência liminar do pedido representa um avanço teórico. Estudos realizados por José Eduardo Arruda Alvim Netto (2017), Trícia Navarro Xavier Cabral (2016), Cassio Scarpinella Bueno (2015a, 2015b), Guilherme Rizzo Amaral (2015), Georges Abboud e José Carlos van Cleef de Almeida Santos (2015) explicitam a ocorrência de um aprimoramento na regulação temática, uma vez que, pelas disposições do art. 332 do Código de Processo Civil de 2015, não mais se sustentam algumas das críticas que foram ofertadas, especificamente, às normas previstas no art. 285-A do Código de Processo Civil de 1973. ${ }^{9}$

É de se considerar, portanto, que nem todos os deficits técnico-científicos relativos ao julgamento liminar pela improcedência do pedido foram afastados pelas normas do Código de Processo Civil de 2015. Sequer é factível afirmar que, com a publicação da Lei $n^{\circ} 13.105 / 15$, a improcedência liminar do pedido alinhou-se à democraticidade jurídica. A regulação do julgamento liminar pela improcedência do pedido no Código de Processo Civil de 2015 apenas possibilitou a oferta de problematizações que, com base nas determinações da Lei no 11.277/06, não poderiam ser formalizadas, dentre as quais a atinente à verificação solipsista da prescrição pelo juiz.

9 Para acessar quatorze questionamentos consistentes relativos à normatividade disposta no art. 285-A do CPC/73, confira os escritos produzidos por Cassio Scarpinella Bueno (2011), Ronaldo Brêtas de Carvalho Dias e Carlos Henrique Soares (2011), Humberto Theodoro Júnior (2009), Elpídio Donizette Nunes (2009), Antônio da Costa Machado (2008), Rosemiro Pereira Leal (2007), Luiz Guilherme Marinoni e Sérgio Cruz Arenhart (2007), Nelson Nery Junior e Rosa Maria de Andrade Nery (2007), Paulo Roberto de Gouvêa Medina (2006) e Eduardo Cambi (2006). 


\section{JULGAMENTO LIMINAR PELA IMPROCEDÊNCIA E A IMPOSSIBILIDADE DE RENÚNCIA À PRESCRIÇÃO NO ESPAÇO PROCEDIMENTAL PRÉ-DECISÓRIO}

O Código de Processo Civil de 2015 dispõe sobre o reconhecimento judiciário da prescrição da pretensão deduzida pela parte autora por via de disposições variadas. Quanto aos procedimentos destinados ao acertamento de direitos, destacam-se as normas previstas nos arts. $332, \S 1^{\circ}$, e 487 , parágrafo único, que, embora sejam acordes quanto à possibilidade de reconhecimento da prescrição, ex officio, pelo juiz, divergem, parcialmente, acerca da necessidade de que, antes de afirmada a ocorrência da prescrição, seja ofertada às partes a oportunidade de se manifestarem a respeito.

É que, apesar do art. $5^{\circ}, \mathrm{LV}$, da Constituição, assegurar o contraditório às partes - o que também se extrai das normas fundamentais do processo civil (arts. $7^{\circ}, 9^{\circ}$ e 10 da Lei $n^{\circ}$ 13.105/15) -, pelo art. 487, parágrafo único, do Código de Processo Civil de 2015, a oportunidade de pronunciamento das partes sobre a prescrição deve ser instalada, desde que não preenchida a hipótese prevista no art. 332 , $\S 1^{\circ}$, da Lei $n^{\circ} 13.105 / 15$.

Daí, pelo disposto nos arts. $332, \S 1^{\circ}$, e 487, parágrafo único, parte final, do Código de Processo Civil de 2015, excepciona-se a obrigatoriedade de oitiva das partes antes do proferimento da decisão que reconhece a ocorrência da prescrição, com explícita violação de norma constitucional e, também, de normas fundamentais integrantes da própria codificação, uma vez que, de acordo com o art. $9^{\circ}$, parágrafo único, do CPC vigente, apenas nas hipóteses de tutela provisória de urgência, de tutela provisória de evidência baseada nos incisos II e III do art. 311 e de ação monitória, a decisão contrária a uma das partes pode ser prolatada sem que ela seja previamente ouvida.

Por esses motivos, o que está disposto na parte final do art. 487, parágrafo único, do Código de Processo Civil de 2015, que ratifica o previsto no art. 332, $\S 1^{\circ}$, do mesmo Código, já foi, especialmente, criticado por Fredie Didier Júnior (2018), José Miguel Garcia Medina (2017), Ronaldo Brêtas de Carvalho Dias, Carlos Henrique Soares, Suzana Oliveira Marques Brêtas, Renato José Barbosa Dias e Yvonne Mól Brêtas (2016), Flávio Tartuce (2016), Georges Abboud e José Carlos van Cleef de Almeida Santos (2015) e Humberto Theodoro Júnior, o qual, ao se pronunciar sobre o reconhecimento judicial da prescrição da pretensão deduzida, afirma:

Malgrado o Código dispense a manifestação prévia dos litigantes na hipótese em análise, nenhum juiz tem, na prática, condições de, pela simples leitura da inicial, reconhecer ou rejeitar uma prescrição. Não se trata de uma questão apenas de direito, como é a decadência, que se afere por meio de um simples cálculo do tempo ocorrido após o nascimento do direito potestativo de duração predeterminada. A prescrição não opera ipso iure; envolve necessariamente fatos verificáveis no exterior da relação jurídica, cuja presença ou ausência são decisivas para a configuração da causa extintiva da pretensão do credor insatisfeito. Sem dúvida, as questões de fato e de direito se entrelaçam profundamente, de sorte que não se pode tratar a prescrição como uma simples questão de direito que o juiz possa, ex officio, levantar e resolver liminarmente, sem o contraditório entre os litigantes. A prescrição envolve, sobretudo, questões de fato, que, por versar sobre eventos não 
conhecidos pelo juiz, o inibem de pronunciamentos prematuros e alheios às alegações e conveniências dos titulares dos interesses em confronto.

Se é difícil para o juiz decretar ex officio e liminarmente a prescrição objetiva do Código Civil (arts. 189, 205 e a maioria dos incisos do art. 206), impossível será fazê-lo nos casos de prescrição subjetiva, como a do art. 27 do Código de Defesa do Consumidor e alguns incisos do art. 206 do Código Civil. É que nesses casos, além da interferência dos impedimentos, interrupções e suspensões, há a imprecisão do termo inicial da prescrição que se relaciona com um dado pessoal e subjetivo: a data do "conhecimento do dano e de sua autoria".

Outras leis que autorizam decretação de prescrição no terreno tributário, sem provocação da parte devedora, não o fazem, todavia, sem condicionar a decisão a uma prévia audiência da Fazenda credora (Lei 6.830/1980, art. 40, $\left.\S 4^{\circ}\right)$, cautela que, com a devida vênia, não poderia ter sido omitida pelo novo Código de Processo Civil a pretexto de rejeição liminar do pedido. (2015, p. 761).

As fragilidades prático-teóricas alusivas à decretação da prescrição sem a prévia oitiva da parte autora não se apresentam como novidades. Antes mesmo do advento do Código de Processo Civil de 2015, Caetano Levi Lopes (2007, p. 14) já anunciava que a legislação brasileira deixava de considerar que a prescrição "é muito mais complexa e demanda um aprofundamento mais amplo na prova do que a decadência. Ocorre que o prazo do derradeiro instituto é peremptório e nada impede, suspende ou interrompe o seu curso. Assim, fica extremamente fácil para o juiz pronunciar, de ofício, a decadência", ao contrário do que se dá com a prescrição.

Entretanto, não é apenas isso que deve ser problematizado. Ao autorizar que o reconhecimento judiciário da prescrição ocorra sem que, antes, seja deferida à parte ré a oportunidade de pronunciamento, o Código de Processo Civil de 2015 também lhe causa prejuízo jurídico, porque, não obstante a decisão proferida com base no art. $332, \S 1^{\circ}$, seja desfavorável à parte autora, a dispensa de oitiva da parte ré é impositiva de óbice ao exercício da faculdade de renúncia à prescrição, a qual, além de lhe ser expressamente garantida pela norma prevista no art. 191 do Código Civil, é assegurada pelo direito à autonomia privada que se impõe como uma das bases normativas do paradigma do Estado Democrático de Direito (art. $1^{\circ}$ da CB). ${ }^{10}$

É de se registrar, nesse sentido, que, não obstante previsão expressa de que a prescrição atinge a pretensão nascida da violação de um direito (art. 189 do Código Civil), nada impede que a parte ré renuncie à prescrição apenas para que tenha a oportunidade de torná-la formalmente resistida, nos exatos termos das cogitações liebmanianas sobre a lide. ${ }^{11}$ Nesse caso, abrir-se-ia a possibilidade de obtenção de uma sentença de mérito desfavorável ao pedido formulado pelo autor, pela qual se acertaria que a parte ré jamais praticou o ato violador de direitos que lhe tenha sido imputado.

10 Sobre o status democrático conferido ao direito pela perspectiva da teoria neoinstitucionalista do processo, confira, sobretudo, as produções de Rosemiro Pereira Leal (2017a, 2016a, 2016b, 2013), Roberta Maia Gresta (2014), André Del Negri (2017), Francisco Dourado Rabelo de Andrade (2017), Luís Henrique Vieira Rodrigues (2019), Vinícius Lott Thibau (2018), Bruno Rodrigues Leite (2017), João Carlos Salles de Carvalho (2018), Dário José Soares Júnior (2016) e Luís Gustavo Reis Mundim (2018), Flávia Ávila Penido (2016) e Luiz Sérgio Arcanjo dos Santos (2016).

11 A respeito da temática, confira a publicação de Enrico Tullio Liebman (2001). 
Com efeito, embora o decisum que reconheça a ocorrência da prescrição por ato solitário do magistrado seja, prima facie, prejudicial apenas à parte autora, é, igualmente, danoso para a parte ré, que, diante da improcedência liminar do pedido, encontra-se impossibilitada, ainda no início do procedimento, de optar por adimplir, em razão de personalíssimas convicções éticas ou morais, uma obrigação natural advinda da ocorrência da prescrição da pretensão deduzida pela parte autora, vendo-se impedida, também, de sustentar e ver acertada, a seu favor, a inexistência pretérita de violação de direitos.

Conforme afirmam Cristiano Chaves de Farias e Nelson Rosenvald (2017, p. 739-740), no âmbito do direito privado, a prescrição é disponível e, por isso:

[...] não se pode deixar de pontuar o lastimável equívoco do legislador em permitir que seja ela conhecida ex officio pelo juiz. Independentemente de qualquer justificativa com base na economia e celeridade processuais, é certo que a sua natureza privada e disponível não justificam o seu conhecimento de ofício. Todavia, com a redação do art. 487, II, do Código de Processo Civil de 2015 as dúvidas restam dissipadas, não sem uma evidente estranheza, restando assentado que, realmente, o magistrado pode, motu proprio, conhecer a prescrição, apesar de estar, com isso, se imiscuindo em uma relação nitidamente privada (patrimonial).

Aliás, convém anotar que o fato de ter o Código de Processo Civil permitido ao magistrado conhecer, ex officio, a prescrição não importou em alteração de sua natureza privada. Tanto que continua sendo possível a renúncia à prescrição, por exemplo através do pagamento espontâneo de uma dívida prescrita. Trata-se de mera consequência da própria autonomia privada, decorrente da própria liberdade assegurada constitucionalmente. Nessa tocada, inclusive, foi editado o Enunciado 295 da Jornada de Direito Civil afirmando que o fato de poder o magistrado reconhecer "de ofício da prescrição, não retira do devedor a possibilidade de renúncia admitida o art. 191 do Texto Codificado".

O que não se esclarece pelo discurso do Enunciado n 295 da VII Jornada de Direito Civil do Conselho da Justiça Federal, no entanto, assim como pelas disposições do Código de Processo Civil de 2015, é de que modo poderá ser realizada a renúncia à prescrição pela parte ré, na hipótese em que o juiz acolhe a ocorrência da prescrição antes mesmo de determinar a citação, como autorizam as normas previstas nos arts. $332, \S 1^{\circ}$ e 487 , parágrafo único, parte final, do Código de Processo Civil de 2015.

$\mathrm{Na}$ Lei $\mathrm{n}^{\circ} 13.105 / 15$, bem como no discurso do Enunciado n 295 da VII Jornada de Direito Civil do Conselho da Justiça Federal, não há qualquer procedimento estabelecido ao exercício da renúncia à prescrição em espaço-tempo que preceda o instante do julgamento liminar pela improcedência.

\section{CONCLUSÁO}

Com base no articulado, conclui-se que, se o magistrado exercer a faculdade disposta no art. 332, $\S 1^{\circ}$, do Código de Processo Civil de 2015, estará violado o direito à autonomia privada de que é titular a parte ré. Caso realizado o julgamento liminar pela improcedência 
do pedido por prescrição, portanto, ocorrerá uma lesão à norma constitucional alinhada à democraticidade jurídica, autorizada por legislação infraconstitucional.

Nessa hipótese, impõe-se dano jurídico à parte ré, a qual, diante da improcedência liminar do pedido, terá obstado o seu direito de renunciar à prescrição no espaço procedimental instaurado ao acertamento de direitos.

\section{REFERÊNCIAS}

ABBOUD, Georges; SANTOS, José Carlos van Cleef de. Da improcedência liminar do pedido no CPC/2015. In: WAMBIER, Teresa Arruda Alvim et al (Coord.). Breves comentários ao novo Código de Processo Civil. São Paulo: Revista dos Tribunais, 2015.

AMARAL, Guilherme Rizzo. Comentários às alterações do novo CPC. São Paulo: Revista dos Tribunais, 2015.

ARRUDA ALVIM NETTO, José Eduardo. Manual de direito processual civil: teoria geral do processo e processo de conhecimento. 17. ed. rev., atual. e ampl. São Paulo: Revista dos Tribunais, 2017.

ASSIS, Araken de. Processo civil brasileiro: parte especial; procedimento comum (da demanda à coisa julgada). São Paulo: Revista dos Tribunais, 2015. v. III.

BRASIL. Código de Processo Civil (1973). Lei n. 5.869, de 11 de janeiro de 1973. Institui o Código de Processo Civil. Disponível em: http://www.planalto.gov.br/ccivil_03/leis/L5869impressao.htm. Acesso em: 6 jul. 2020.

BRASIL. Constituição (1988). Constituição da República Federativa do Brasil. Brasília: Senado Federal, Centro Gráfico, 1988.

BRASIL. Lei n. 11.277, de 7 de fevereiro de 2006. Acresce o art. 285-A à Lei no 5.869, de 11 de janeiro de 1973, que institui o Código de Processo Civil. Disponível em: http://www.planalto.gov.br/ccivil_03/_Ato2004-2006/2006/ Lei/L11277.htm. Acesso em: 6 jul. 2020.

BRASIL. SENADO FEDERAL. Anteprojeto do novo Código de Processo Civil: comissão de juristas responsável pela elaboração do anteprojeto do novo Código de Processo Civil. Brasília: Subsecretaria de Edições Técnicas, 2010.

BRASIL. SENADO FEDERAL. Código de processo civil e normas correlatas. 7. ed.. Brasília: Coordenação de Edições Técnicas, 2015. Disponível em: https://www2.senado.leg.br/bdsf/bitstream/handle/id/512422/001041135. pdf. Acesso em: 6 jul. 2020.

BRÊTAS, Ronaldo C. Dias et al. Estudo sistemático do NCPC: com as alterações introduzidas pela lei n. 13.256, de 4/2/2016. Belo Horizonte: D'Plácido, 2016.

BRÊTAS, Ronaldo C. Dias; SOARES, Carlos Henrique. Manual elementar de processo civil. Belo Horizonte: Del Rey, 2011.

BUENO, Cassio Scarpinella. Novo Código de Processo Civil anotado. São Paulo: Saraiva, 2015a.

BUENO, Cassio Scarpinella. Manual de direito processual civil: volume único. São Paulo: Saraiva, 2015b.

BUENO, Cassio Scarpinella. Curso sistematizado de direito processual civil: procedimento comum - procedimento ordinário e sumário. 4. ed. rev., atual. e ampl. São Paulo: Saraiva, 2011. v. 2, t. I.

CABRAL, Trícia Navarro Xavier. A improcedência liminar do pedido e o saneamento do processo. Revista de Processo, São Paulo, v. 252, fev. 2016. Disponível em: http://www.mpsp.mp.br/portal/page/portal/documentacao_e_ divulgacao/doc_biblioteca/bibli_servicos_produtos/bibli_boletim/bibli_bol_2006/RPro_n.252.07.PDF. Acesso em: 15 fev. 2019.

CAMBI, Eduardo. Julgamento prima facie [imediato] pela técnica do art. 285-A do CPC. Argumenta Journal of Law: Revista do Programa de Mestrado em Ciência Jurídica da Fundinopi. Jacarezinho, v. 6, p. 153-178, 2006. 
CARVALHO, João Carlos Salles de. Pedagogia judicial e processo democrático: a fala processual como exercício de cidadania. Belo Horizonte: D'Plácido, 2018.

CASTRO, Bernardo Vassalle de. A participação social no processo legislativo e o desenvolvimento sustentável. In: Veredas do Direito: Direito Ambiental e Desenvolvimento Sustentável, Belo Horizonte, volume especial 7, n. 13 e 14, p. 213-239, jan./dez. 2010.

COSTA MACHADO, Antônio da. Código de Processo Civil interpretado: artigo por artigo, parágrafo por parágrafo. 2. ed. Barueri: Manole, 2008.

DEL NEGRI, André. Controle de constitucionalidade no processo legislativo. 3. ed. rev., atual. e ampl. Belo Horizonte: D'Plácido, 2017.

DIDIER JR., Fredie. Curso de direito processual civil: introdução ao direito processual civil, parte geral e processo de conhecimento. 20. ed. rev., atual. e ampl. Salvador: Juspodivm, 2018. v. 1.

DOURADO DE ANDRADE, Francisco Rabelo. Tutela de evidência, teoria da cognição e processualidade democrática. Belo Horizonte: Fórum, 2017.

FARIAS, Cristiano Chaves; ROSENVALD, Nelson. Curso de direito civil: parte geral e LINDB. 15. ed. Salvador: Juspodivm, 2017.

GRESTA, Roberta Maia. Introdução aos fundamentos da processualidade democrática. Rio de Janeiro: Lumen Juris, 2014. (Coleção Estudos da Escola Mineira de Processo, v. 1).

HABERMAS, Jürgen. Direito e democracia: entre facticidade e validade. Tradução de Flávio Beno Siebeneichler. 2. ed. Rio de Janeiro: Tempo Brasileiro, 2003. v. 2.

LEAL, André Cordeiro; THIBAU, Vinícius Lott. A estrutura fundamental do direito processual dogmático e suas repercussões no Código de Processo Civil brasileiro de 2015. In: OMMATI, José Emílio Medauar; DUTRA, Leonardo Campos Victor (Coord.). Teoria crítica do processo: contributos da escola mineira de processo para o constitucionalismo democrático. Rio de Janeiro: Lumen Juris, 2018. (Coleção Teoria Crítica do Direito, v. 6).

LEAL, André Cordeiro; THIBAU, Vinícius Lott. Prova e jurisdicionalismo no novo CPC brasileiro. Revista Meritum, Belo Horizonte, v. 12, n. 2, p. 36-52, jul./dez. 2017. Disponível em: http://www.fumec.br/revistas/meritum/article/ view/5226/pdf. Acesso em: 6 jul. 2020.

LEAL, Rosemiro Pereira. Processo como teoria da lei democrática. 2. ed. Belo Horizonte: Fórum, 2017a.

LEAL, Rosemiro Pereira. A questão dos precedentes e o devido processo. Revista Brasileira de Direito Processual - RBDPro, Belo Horizonte, ano 25, n. 98, p. 295-313, abr./jun. 2017 b.

LEAL, Rosemiro Pereira. Teoria processual da decisão jurídica. 2. ed. Belo Horizonte: D'Plácido, 2016a. (Coleção Direito e Justiça).

LEAL, Rosemiro Pereira. Teoria geral do processo: primeiros estudos. 13. ed. rev., atual. e aum. Belo Horizonte: Fórum, 2016b.

LEAL, Rosemiro Pereira. A teoria neoinstitucionalista do processo: uma trajetória conjectural. Belo Horizonte: Arraes, 2013. (Coleção Professor Álvaro Ricardo de Souza Cruz, v. 7).

LEAL, Rosemiro Pereira. Parte como instituto do processo constitucional. In: CASTRO, João Antônio Lima; FREITAS, Sérgio Henriques Zandona (Coord.). Direito processual. Belo Horizonte: PUC Minas - Instituto de Educação Continuada, 2011.

LEAL, Rosemiro Pereira. O due process e o devir processual democrático. Revista da Faculdade Mineira de Direito, Belo Horizonte, v. 13, n. 26, p. 99-115, jul./dez. 2010.

LEAL, Rosemiro Pereira. Modelos processuais e constituição democrática. In: CATTONI DE OLIVEIRA, Marcelo Andrade; MACHADO, Felipe Daniel Amorim. Constituição e processo: a contribuição do processo ao constitucionalismo democrático brasileiro. Belo Horizonte: Del Rey, 2009.

LEAL, Rosemiro Pereira. O paradigma processual ante as seqüelas míticas do poder constituinte originário. Revista da Faculdade de Direito da UFMG, Belo Horizonte, n. 53, p. 295-316, jul./dez. 2008. 
LEAL, Rosemiro Pereira. A judiciarização do processo nas últimas reformas do CPC brasileiro. In: BRÊTAS, Ronaldo C. Dias; NEPOMUCENO, Luciana Diniz (Coord.). Processo civil reformado. Belo Horizonte: Del Rey, 2007, p. 253270.

LEAL, Rosemiro Pereira. Direitos fundamentais do processo na desnaturalização dos direitos humanos. Revista da Faculdade Mineira de Direito, Belo Horizonte, v. 9, n. 17, p. 89-100, 2006.

LIEBMAN, Enrico Tullio. Estudos sobre o processo civil brasileiro. Araras: Bestbook, 2001.

LEITE, Bruno Rodrigues. A população em situação de rua e o mandado de segurança. Belo Horizonte: D'Plácido, 2017.

LOPES, Caetano Levi. A prescrição pronunciada de ofício e seus reflexos no direito material e no direito processual. In: BRÊTAS, Ronaldo C. Dias; NEPOMUCENO, Luciana Diniz (Coord.). Processo civil reformado. Belo Horizonte: Del Rey, 2007, p. 9-20.

MARINONI, Luiz Guilherme; ARENHART, Sérgio Cruz. Processo de conhecimento. 6. ed. rev., atual e ampl. São Paulo: Revista dos Tribunais, 2007.

MEDINA, José Miguel Garcia. Curso de direito processual civil moderno. 3. ed. rev., atual. e ampl. São Paulo: Revista dos Tribunais, 2017.

MEDINA, Paulo Roberto de Gouvêa. Sentença emprestada: uma nova figura processual. Revista de Processo, São Paulo, v. 135, p. 152-160, maio 2006.

MUNDIM, Luís Gustavo Reis. Precedentes: da vinculação à democratização. Belo Horizonte: D'Plácido, 2018.

NERY JUNIOR, Nelson; NERY, Rosa Maria de Andrade. Código de Processo Civil comentado e legislação extravagante. 10. ed. rev., ampl. e atual. São Paulo: Revista dos Tribunais, 2007.

NUNES, Elpídio Donizette. Curso didático de direito processual civil. 11. ed. atual. e ampl. Rio de Janeiro: Lumen Juris, 2009.

PENIDO, Flávia Ávila. Processo e interpretação em Eduardo J. Couture. Rio de Janeiro: Lumen Juris, 2016.

POPPER, Karl Raimund. O conhecimento e o problema corpo-mente. Tradução de Joaquim Alberto Ferreira Gomes. Lisboa: Edições 70, 2009.

POPPER, Karl Raimund. A lógica da pesquisa científica. Tradução de Leonidas Hegenberg e Octanny Silveira da Mota. São Paulo: Cultrix, 2004.

POPPER, Karl Raimund. Conhecimento objetivo: uma abordagem evolucionária. Tradução de Milton Amado. Belo Horizonte: Itatiaia, 1999.

RODRIGUES, Luís Henrique Vieira. Tutela de emergência processual. Belo Horizonte: D'Plácido, 2019.

SANTOS, Luiz Sérgio Arcanjo dos. Processo e poder constituinte originário: a construção do direito na processualidade jurídico-democrática. Rio de Janeiro: Lumen Juris, 2016.

SOARES JÚNIOR, Dário José. A crise dogmática do processo penal. Belo Horizonte: D'Plácido, 2016.

TARTUCE, Flávio. Direito civil: lei de introdução e parte geral. 12. ed. rev., atual. e ampl. Rio de Janeiro: Forense, 2016. v. 1.

THEODORO JÚNIOR, Humberto. Curso de direito processual civil: teoria geral do direito processual civil, processo de conhecimento e procedimento comum. 56. ed. rev., atual. e ampl. Rio de Janeiro: Forense, 2015. v. 1.

THEODORO JÚNIOR, Humberto. Curso de direito processual civil: teoria geral do direito processual civil e processo de conhecimento. 50. ed. Rio de Janeiro: Forense, 2009. v. 1.

THIBAU, Vinícius Lott. Apontamentos críticos sobre a improcedência liminar do pedido. Revista Eletrônica de Direito do Centro Universitário Newton Paiva, n. 37, p. 43-59, jan./abr., 2019.

THIBAU, Vinícius Lott. Garantismo e processualidade democrática. Belo Horizonte: D'Plácido, 2018.

Recebido/Received: 22.07.2020. 